$18: 1662$

$<$ 原 著 $>$

Radioimmunoassay 法による $\mathrm{HBe}$ 抗原・抗体と血中

DNA polymerase 活性及び血中 Dane 粒子の B 型

慢性肝疾患患者における経時的変動について

$\begin{array}{lrlr}\text { 水野 } & \text { 元夫 } & \text { 山田剛太郎 坂本 裕治 } \\ \text { 西原 } & \text { 隆 } & \text { 長島, 秀夫* } & \end{array}$

要 旨：25例の HBs 抗原陽性慢性肝疾患患者の血清95検体を用いて経時的に Radioimmunoassay (RIA) 法で HBe 抗原・抗体を湘定し, 同時に血中 DNA polymerase (DNA-P) 活性, Dane 粒 子を検索し両者の関連を検討した. RIA 法で HBe 抗原陽性群の DNA-P 活性は HBe 抗体陽性 群に比し有意に高值を示したが, HBe 抗原陽性群でも約1/3の検体で DNA-P 活性は低值を示し た．急性增悪を伴う慢性肝咨10例の経時的観察では，HBe 抗原持続陽性例は 4 例で，亏ち 3 例 では DNA-P 活性は常時高くDane 粒子も多く観察されたが，1例では DNA-P 活性もたえず低 くDane 粒子もごく少数であった．急性增悪期に一致して HBe 抗原から HBe 抗体または判定 保留へと変動を示した 4 例中 3 例では, DNA-P 活性や Dane 粒子の增減が注活平行して経過し たが，1例では急性増悪時にもDNA-P 活性やDane 粒子は低值のままであった。経過中主とし て HBe 抗体が検出された 2 例では, 急性増悪期に HBe 抗体陽性ないし判定保留でる一過性に DNA-P 活性の上昇や Dane 粒子の増加が観察された。

索引用語： $\mathrm{HBe}$ 抗原 $\mathrm{HBe}$ 抗体 Radioimmunoassay DNA polymerase B 型慢性肝疾患

はじめに

1972年に Magnius ら"により発見された HBe 抗原・ 抗体系についてはその後の研究により, HBe 抗原陽 性血中には多数の Dane 粒子が出現 $L^{2,3)}$ ， Hepatitis B virus (HBV) associated DNA polymerase (DNA-P) 活 性が高く ${ }^{3,4,5)}$ ，また臨床的には HBe 抗原が垂直及び 水平感染に括ける感染性の指標となることが報告さ $れ^{4,6,7)} ， そ し て, 1979$ 年には真弓らのグループによって HBe 抗原が Dane 粒子の内部粒子にも存在しているこ とが明らかにされだ)。しかしながら従来 HBe 抗原・ 抗体の検出に用いられてきた Micro Ouchterlony (MO) 法では, $\mathrm{HBe}$ 抗原の検出されない検体でも DNA-P 活 性の高いものが少数認ぬられる ${ }^{5,9)}$ なと，HBe 抗原・抗

* 岡山大学第 1 内科

<受付日56年 7 月 10 日 $>$
体系と DNA-P 活性の若干の解離も指摘されている. たB型慢性肝疾患沈拁りる HBe 抗原・抗体の意義につ いてる， HBe 抗原陽性例儿活動性例の多いこと ${ }^{10,11}$ な どが報告されているが，いまだ十分に解明されたとは言 えず， $\mathrm{HBe}$ 抗原・抗体系の詳細な检討にはより感度の 高い検出法が望まれていた。今回我々は，HBs 抗原陽性 慢性肝疾患患者比招いて Radioimmunoassay (RIA) 法 により $\mathrm{HBe}$ 抗原・抗体を測定し，また血中 $\mathrm{HBV}$ の指 標として血中 DNA-P 活性と血中 Dane 粒子を梌索し て両者の関連を険討した．さらに，GOT，GPT の一過 性上昇で示されるような急性増悪を伴ら慢性肝资患者 で HBe 抗原・抗体及び血中 HBV の経時的変化を観察 し，急性堌悪との関連についても若干の知見を得たので 報告する。

\section{対象ならびに方法}

対象 は岡山大学第 1 内科に入院し血中 HBs 抗原持 
続陽性の症例で，腹朌鏡下肝生検をもとにヨーロッパ 分類 ${ }^{12)}$ に従って診断した Chronic aggressive hepatitis (CAH) 21例, Liver cirrhosis 4 例 (5ち2例は Hepatocellular carcinoma を合併）である. CAH の21例中 GOT, GPT の大きく変動する症例で，副腎皮質ホルモ ン，免疫抑制剤等の特殊な治療を施していない症例のら ち10例について HBe 抗原 - 抗体と血中 DNA-P 活性, 血 中 Dane 粒子との関連を 6 カ月から16カ月にわたり経時 的に観察した.これら対象より得られた血清95検体と， 対照として HBs 抗原・抗体共に陰性の健康人 7 人上り の血清 7 検体についてて，HBe 抗原・抗体は MO 法 ${ }^{2}$ 及 び Dainabot 社より提供された RIA $\mathbf{k i t}^{\text {(3) }}$ を用いて測定 した. RIA 法では, 原血清で HBe 抗原が陽性ながら DNA-P 活性高值 $(885 \mathrm{cpm})$ と低值 $(179 \mathrm{cpm})$ の 2 種 類の検体を用いてそれぞれ倍数希积し HBe 抗原の希积 曲線を作成した．その結果に基づき，原血清の RIA 法 で HBe 抗原が陽性を示した検体ではさらに，100倍希 釈した血清を用いて HBe 抗原を測定した。な拉 RIA 法での HBe 抗原 ・抗体の測定結果は鈴木らの基準(1) $儿$ 従って判定した．血中 DNA-P 活性は血清 $1 \mathrm{~m} l$ を超遠 心法にて10倍に潧縮した Dane particles rich suspension

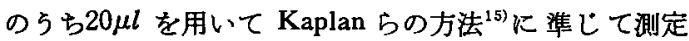
した. また，Dane particles rich suspension の一部をリ ンタンタステン酸で negative 染色し電子影改鏡下にて Dane 粒子の有無を観察し, 400mesh の grid opening K 出現する Dane 粒子の数により grade 0 ＩI までの 4 段階に分類した ${ }^{16)}$ 。

\section{成 績}

1) RIA 法で測定した HBe 抗原・抗体と血中 DNA$\mathbf{P}$ 活性との関連

原血清での RIA 法による HBe 抗原・抗体の測定結 果と DNA-P 活性との関連を Fig. 1 に示した. HBs 抗 原陽性の95検体中 HBe 抗原か陽性を示したのは57検体 でその DNA-P 活性住平均 $656 \mathrm{cpm}$ (standard deviation, $\mathrm{SD},=840 \mathrm{cpm}$ ), 判定保留は16検体で DNA-P 活性は平 均243cpm (SD=170cpm)，HBe 抗体陽性は22検体で DNA-P 佸性は平均 $180 \mathrm{cpm}(\mathrm{SD}=98 \mathrm{cpm})$ であった。 HBs 抗原・抗体共に陰性の健康人 7 人 97 娭体では HBe 抗原・抗体は共に陰性で，その DNA-P 活性は平 均122cpm（SD=27cpm）であった. HBe 抗原陽性群の DNA-P 活性は, 判定保留群, $\mathrm{HBe}$ 抗体陽性群, 健康 人対照群に比し有意に（それぞれ $p<0.01 ， p<0.001$ ， p<0.001）高值を示したか， HBe 抗原陽性57検体中19

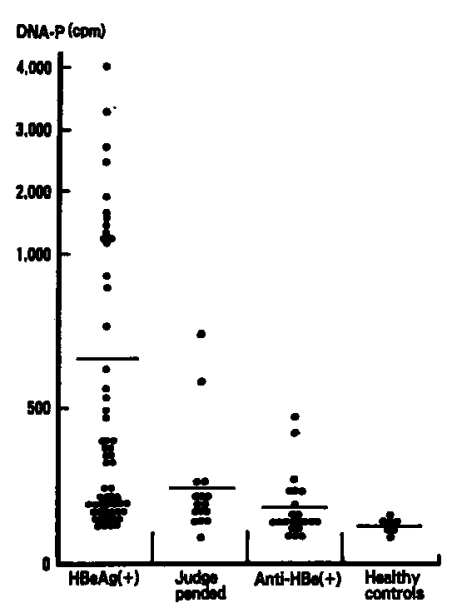

Fig. 1 Correlation between DNA-P activity and $\mathrm{HBeAg} /$ anti-HBe determined by RIA in original sera. Horizontal line : mean value of DNA-P activity of each group.

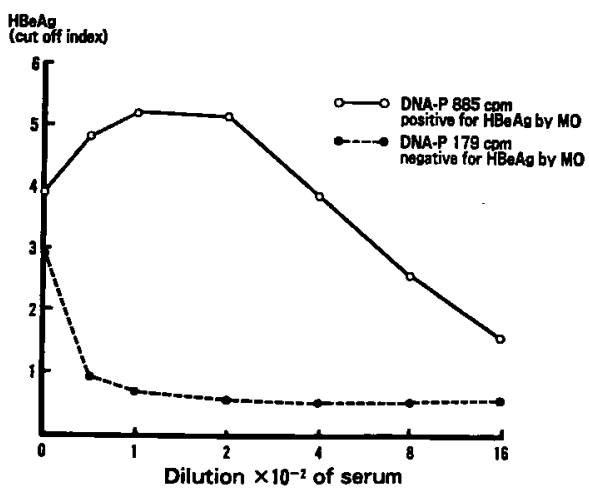

Fig. 2 Detection of HBeAg by RIA in serial dilutions of 2 sera positive for HBeAg by RIA in original sera; one with high DNA-P activity and positive for $\mathrm{HBeAg}$ by $\mathrm{MO}$ and the other with low DNA-P activity and negative for $\mathrm{HBeAg}$ by MO.

検体 (33\%) では， DNA-P 活性は HBe 抗体陽性群の 平均 $180 \mathrm{cpm}$ より低い值を示した。判定保留群の 2 検体 と HBe 抗体陽性の 2 検体で DNA-P 活性が $400 \mathrm{cpm}$ 以 上の值を示した.このうち $\mathrm{HBe}$ 抗体陽性の 1 検体では MO 法でる HBe 抗体が検出されたが，電顕的観察では grade II の Dane 粒子が認められた (Fig. 7b).

次に RIA 法での HBe 抗原の倍数希釈曲線を Fig. 2 に示した。 DNA-P 活性の高值であった検体では，800倍 であ $\mathrm{HBe}$ 抗原は陽性であったのに対し， DNA-P 活性 


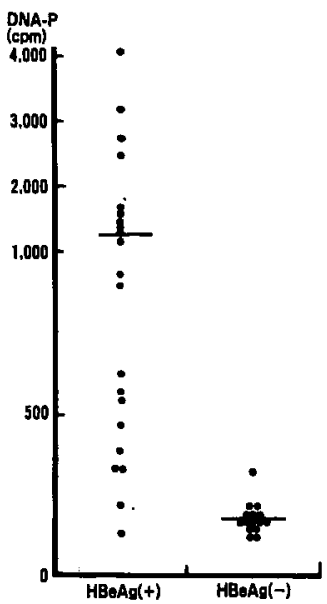

Fig. 3 Correlation between DNA-P activity and $\mathrm{HBeAg}$ determined by RIA in 100 -fold diluted sera originally positive for $\mathrm{HBeAg}$ by RIA.

Table. Comparison between RIA in 100-fold diluted sera and MO method for detection of $\mathrm{HBeAg}$.

\begin{tabular}{cccc}
\hline $\begin{array}{c}\text { RIA } \\
\left(x 10^{-2}\right)\end{array}$ & $\begin{array}{l}\text { No. of } \\
\text { samples }\end{array}$ & \multicolumn{2}{c}{ MO } \\
\hline+ & 20 & 17 & - \\
\hline- & 10 & 0 & 10 \\
\hline total & 30 & 17 & 13 \\
\hline
\end{tabular}

の低值であった検体では，50倍希釈ですでに HBe 抗原 が陰性となった。そして100倍から200倍希釈に捣いて 両者の cut off index の差が最大となった。この結果に 基ついて，原血清を用いた RIA 法により $\mathrm{HBe}$ 抗原 が陽性を示した57検体中36検体では同時に100倍希釈し て HBe 抗原を測定した（Fig. 3).36検体中21検体は 100倍希釈です $\mathrm{HBe}$ 抗原が陽性で， DNA-P 活性は平均 $1,260 \mathrm{cpm}(\mathrm{SD}=1,067 \mathrm{cpm})$ を示し，100倍希积で $\mathrm{HBe}$ 抗原が陰性となった15検体の DNA-P 活性（平均177 $\mathrm{cpm}, \mathrm{SD}=46 \mathrm{cpm})$ に比し有意に（p<0.001）高値を示 しだ.そして, DNA-P 活性が200cpm 以下の低值を示し た13検体では12検体が100倍希积血清で HBe 抗原が陰 性となり，HBe 抗原価は低いわのと考えられた。さら に上記の RIA の100倍希积法々 MO 法との測定を比較 したが，RIA の100倍希积法で HBe 抗原が陽珄の20検 体中17検体では MO 法です HBe 抗原は陽性を示し， 一方，100倍希釈で HBe 抗原陰性の10検体では，MO 法であ全例陰性であった (Table).
2）GOT, GPT の変劰の強いB型惿性肝资10例にお ける HBe 抗原・抗体と血中 DNA-P 活性の経時的覞察 これら10例について6カ月以上にわたり $\mathrm{HBe}$ 抗原・ 抗体と血中 DNA-P 活性, 血中 Dane 粒子の变動を観察 したが，10例のうち RIA 法で経過中 HBe 抗原が常時 陽性例が 4 例， GOT，GPT の変動とともに HBe 抗原 陽性から判定保留ないし $\mathrm{HBe}$ 抗体陽性へと変動した例 が 4 例認められ，残り2 例では経過中主として HBe 抗 体が観察された．HBe 抗原常時陽性の 4 例中 3 例では DNA-P 活性む， $1,000 \mathrm{cpm}$ 以上の高値が続き電䫒でも多 数の Dane 粒子が認められた（代表例を Fig. 4a に示

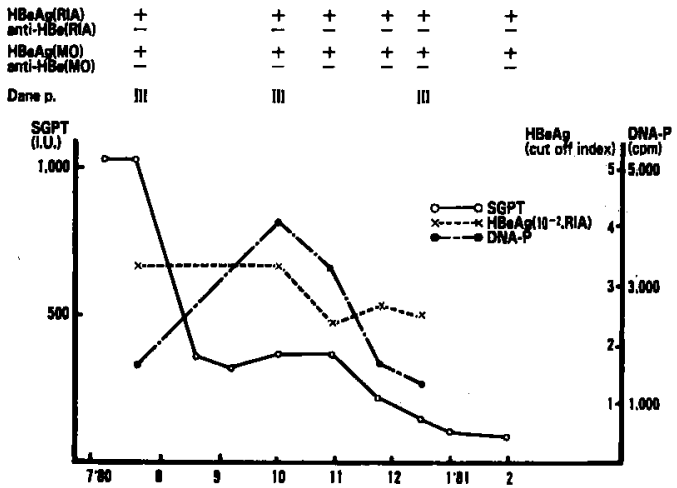

a)
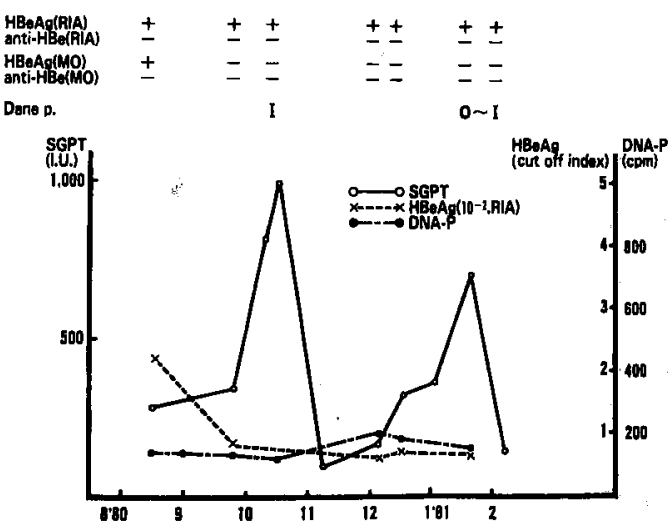

b)

Fig. 4 Serial determinations of $\mathrm{HBeAg} /$ anti-HBe by RIA in original and 100 -fold diluted sera, DNA-P activity and Dane particles in patients with chronic aggressive hepatitis. a) a case with a high titer of HBeAg and high DNA-P activity. b) a case with a low titer of $\mathrm{HBeAg}$ and low DNA-P activity. 
す). 残り 1 例では S-GPT の一過性の上昇で示される急 性增悪時にも DNA-P 活性はたえず低値を示L(Fig. 4b) 血中の Dane 粒子すごく少数しか粺察されなかった(Fig. 7a).これらの症例で100倍希释血清にて HBe 抗原を測 定しその cut off index の経時的変化を観察すると， DNA-P 活性が持続性に高値の症例では， HBe 抗原が 100倍希积血清でる常時陽性であった（Fig. 4a）のに対 し，DNA-P 活性がたえず低値の Fig. 4b の症例では HBe 抗原は100倍希釈では初回を除いて持続性に陰性を 示した。

GOT，GPT の一過性の上昇とともに HBe 抗原から $\mathrm{HBe}$ 抗体ないし判定保留への变動の認められた 4 例中 3例では，急性增覀にほぼ-致して DNA-P 活性の上 昇，Dane 粒子の增加が観察され，代表例を Fig. 5 K 示すが，100倍希积血清に括ける $\mathrm{HBe}$ 抗原の cut off index は，血中 DNA-P 活性や Dane 粒子の增減とよく 一致する変動が認められた。 しかし，他の 1 例では急性 增悪時にす DNA-P 活性の上昇は認められなかった。

10例中 2 例では経過中主として HBe 抗体が検出さ れた (Fig. 6a，b). Fig. 6a の症例では S-GPT の上 昇に先立ち DNA-P 活性 とは Dane 粒子の急増が見ら れ，それに一致して原血清の RIA 法による HBe 抗 原の cut off index 1.9 上上昇し同時に $\mathrm{HBe}$ 抗体の inhibition \%は68\%と低下した。1 週間後の S-GPT の極 期には HBe 抗体は RIA 法及び MO 法で再び陽性に 転したにもかかわらず DNA-P 活性はまだ400cpm 以上

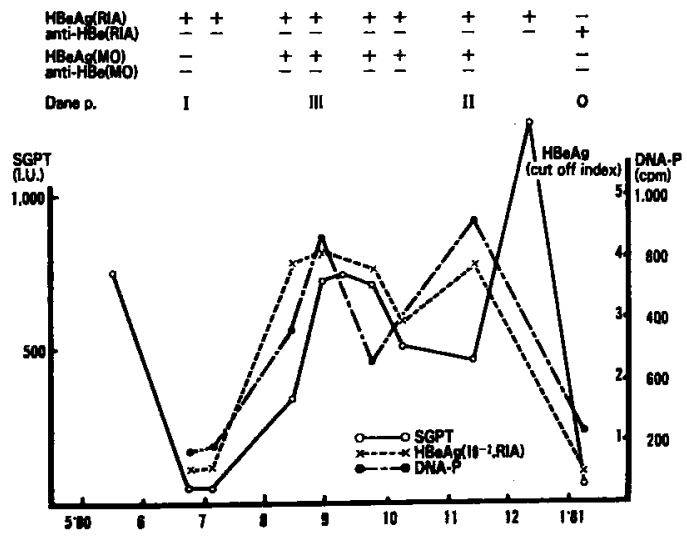

Fig. 5 Serial determinations of $\mathrm{HBeAg} / \mathrm{anti}-\mathrm{HBe}$ by RIA in original and 100 -fold diluted sera, DNA-P activity and Dane particles in a patient with chronic aggressive hepatitis who showed seroconversion from $\mathrm{HBeAg}$ to Anti-HBe.

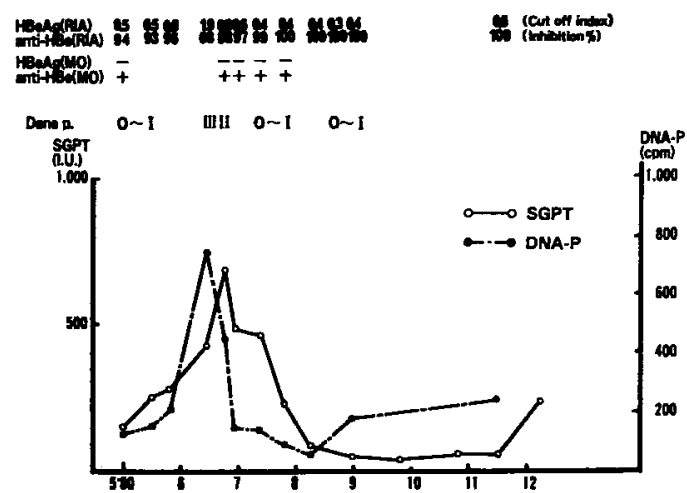

a)

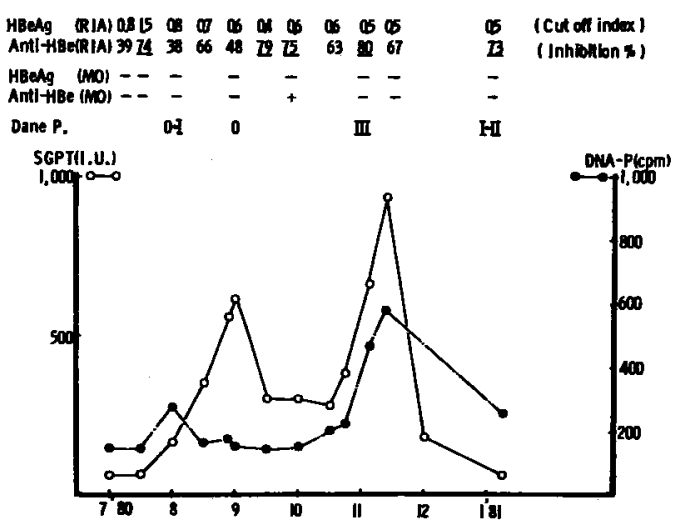

b)

Fig. 6a, b Serial determinations of $\mathrm{HBeAg} /$ antiHBe by RIA, DNA-P activity and Dane particles in patients with chronic aggressive hepatitis, in whom anti-HBe was mainly detected during the course.

の値を示し, 電影下です grade II の Dane 粒子が認め られた (Fig. 7b).そしてその後 HBe 抗体は高值が持 続した. 一方, Fig. 6b の症例では, HBe 抗体陽性ない し判定保留が持続したが，前例と同様に 2 回目のS-GPT の上昇に一致して DNA-P 活性の上昇が認められ，DNA$P$ 活性は400cpm 以上の值を示し電顕下でる grade 吕の Dane 粒子が観察された。しかしながら本例では $\mathrm{HBe}$ 抗原の cut off index は, DNA-P 活性の極期にも0.5と 陰性のままほとんど変動が見られなかった。

MO 法レベルでは一般に，HBe 抗原陽性の血夜で は DNA-P 活性が高く逆に HBe 抗体陽性の血夜では DNA-P 活性が低い,3,4,5)ことが指摘されてきた。従って 


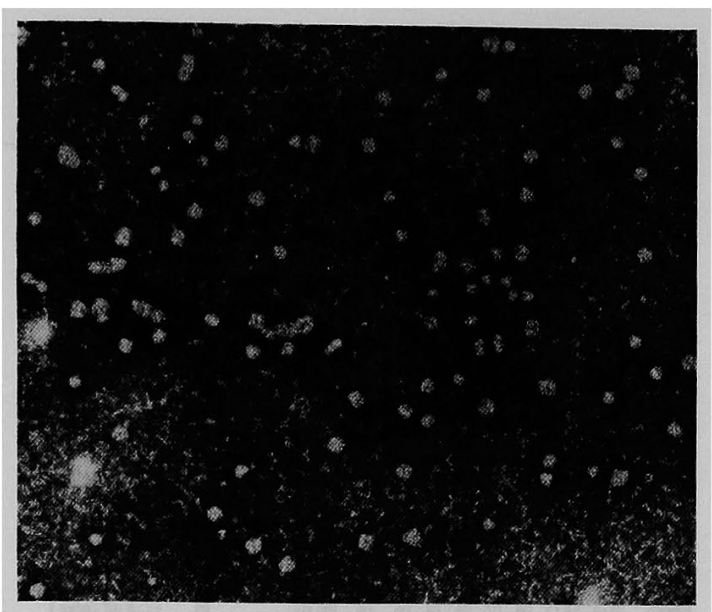

a)

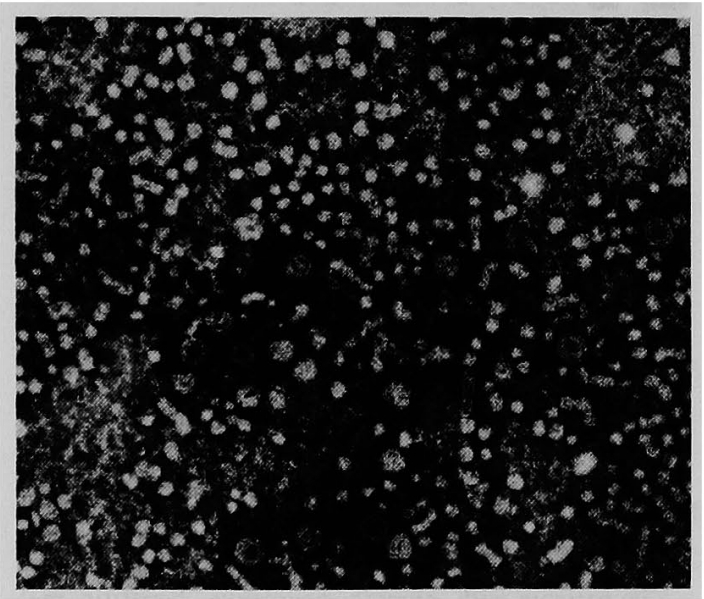

b)

Fig. 7 Electron microscopic observations of Dane particles on 10-fold concentrated sera. a) Dane particles in grade $I$ at the first peak of S-GPT of the case in Fig. $4 \mathrm{~b}(\times 58,000)$. b) Dane particles in grade II at the peak of S-GPT of the case in Fig. $6 \mathrm{a}(\times 58,000)$.

MO 法で HBe 抗原・抗体共に陰性の際には, DNA-P 活性高値例は HBe 抗原陽性群に, DNA-P 活性低值例 は $\mathrm{HBe}$ 抗体陽性群に近いことが想定されてきた 今回の著者らの慢性肝疾患例を対象とした RIA 法レベ ルでの検討では HBe 抗原が陽珄 の57検体中, DNA-P 活性か: HBe 抗体陽性群の平均 $180 \mathrm{cpm}$ よりも低值を示 したものが19検体（33\%）に認められた（Fig. 1). 寸 なわち慢性肝疾患例で泼, RIA 法で $\mathrm{HBe}$ 抗原を測定し た際には，DNA-P 活性が低い検体でも HBe 抗原陽性
を示す例が少なからず存在することが判明した．しかし ながら，このような症例での HBe 抗原は, RIA の100 倍希釈法では大部分陰性となること，また同様に MO 法でむ陰性であることより，その抗原価は低いものと考 えられた。. 次に， $\mathrm{HBe}$ 抗原陽性例の経時的観察は，原 血清と 100倍希釈血清を用いて HBe 抗原を測定したが， Fig. 4, 5 に示すように100倍希瀵血清の変動は DNA-P 活性とよく相関する症例が多く，原血清の RIA 法で HBe 抗原か;陽珄の場合には，同時に100倍希釈血清を用 いた HBe 抗原の測定が血中 HBV の増隇の簡便な指標 として有用であるすのと考觉られた。

一方, $\mathrm{HBe}$ 抗体と DNA-P 活性の関連については, MO 法レベルでの険討で Alberti ら ${ }^{17)}$ は $\mathrm{HBe}$ 抗体陽 性の21検体中 1 検体に DNA-P 活性陽性のbのを認めて いるが，今回著者らの RIA 法レベルの検討では HBe 抗体の陽性であった22検体中 2 検体で DNA-P 活性は $400 \mathrm{cpm}$ 以上の值を示し, このらち 1 検体は MO 法で む $\mathrm{HBe}$ 抗体を検出できた.この2陰体は Fig. 6 に 示された 2 例の慢性肝炎例の急性増悪にほぼ一致して DNA-P 活性の上昇が認められた時期の検体で，DNA-P 活性の上昇ととすに Dane 粒子の増加る観察されたこと から，この DNA-P 活性は HBV に特異的なむのと考え られた. そこで急性増悪期前後の検体では，HBV の増 减と $\mathrm{HBe}$ 抗原の増減との間の解離や時相のずれのため に $\mathrm{HBe}$ 抗体陽性でも多数の $\mathrm{HBV}$ が存在する可能性も あり, transaminase の高い場合には，その感染性の評価 に拈いても十分慎重であるべきことが示唆された．

B 型慢性肝炎の急性增悪の機序については，いまだ一 定の見解は得られていない，しかし，急性増悪の直前か ら極期にかけて血中に多数の Dane 粒子が出現する症 例がしばしば観察され ${ }^{16)}$ ，この時期に一致して DṆA-P 活性の上昇も見られることなどから，急性増悪の直接 の原因であるかどうかは別としてす，HBV の active replication と急性増覀の密接な関連が推測されている. 今回の検討です，急性増覀に一致して Dane 粒子が多 数出玩し， DNA-P 活性が増加する症例が多く，同時に HBe 抗原価の上昇子認められた. GOT, GPT の増悪期 に一致した $\mathrm{HBe}$ 抗原の出現は，MO 法レベルでの検討 で既に鈴木らによって報告されている症例 ${ }^{10)}$ とも一致し ている.しかしながら，Fig. 4b に示すように一部の症 例では，急性増悪にもかかわらず DNA-P 活性の上昇や Dane 粒子の増加が認められず, HBe 抗原価む低値のま までほとんど変動を示さず, HBV の増減や HBe 抗原・ 
抗体の変動を伴わない,GOT, GPT の増悪が観察され ている. かかる症例に拈りる急性增覀の機序は, 単に HBV の active replication ゃ HBe 抗原の増減の及で は理解し難い面があり, 個体の免度応答の差異を含めて な打恰索を要する。

次にこのような急性增覀時に括ける HBe 抗原・抗体 の変動については，前述のシューブに一致した HBe 抗 原価の上昇の他に，MO 法による検討でも，GOT, GPT の増悪を契機に HBe 抗原から HBe 抗体への seroconversion する症例が報告されて括り ${ }^{10,18)}$, 著者らの一 部の症例でる， S-GPT の下降ととあに HBe 抗体への seroconversion が認められた (Fig. 5). さらに赤羽ら は凝集法による測定で，HBe 抗体が高抗体価で持続す るにもかかわらず GOT, GPT が著明に変動する症例 を報告しているが，著者らる少数例ではあるが， $\mathrm{HBe}$ 抗体が 経過中ほ上んど常時陽性でありながら急性增悪 をきたした症例 (Fig. 6a) を経験した。しかし，本例 では S-GPT の上昇に先立ち一過性に DNA-P 活性の 上昇と Dane 粒子の急増が見られ，この時期に一致し $\tau$ HBe 抗原の cut off index の上算と, HBe 抗体の inhibition \%の減少, さらにその後の Booster 效果之思 われる inhibition \%の上昇が観察された。本例は $\mathrm{HBe}$ 抗体優位の状態にむかかわらず, 急性增悪に一致して肝 臓での HBe 抗原と HBV の一過性の增加を推測させ, HBV の active replication の関与を示唆するもので, $\mathrm{HBe}$ 抗体価の変動をほとんど伴っていない赤羽らの症 例とは若千異なるものと思われる。また低值ながらしば しば HBe 抗体の観察された Fig. 6b の症例では, 2 回目の S-GPT の上昇時炕 DNA-P 活性と Dane 粒子の 増加が認められるにもかかわらず, HBe 抗原の cut off index は0.5〜0.6とほとんど変動が見られず，少数例な がら HBe 抗原・抗体の変動と血中 HBV の増隇の間に 解離の見られる症例む観察された。

このよ5に，血中 DNA-P 活性や Dane 粒子ととも に, 上り感度の高いRIA 法で HBe 抗原・抗体の経時 的変化を観察した結果, 血中 HBV の増減と HBe 抗 原・抗体の変動との間には密接な関連を示す症例が多 く認められたが，慢性肝炎の急性增悪期の前後では各個 体により両者の間に微妙な差異が存在する例も少なから ず観察された。 今後, 急性増悪の病態を解明していくた めに, また急性増悪を契機として HBe 抗原の seroconversion の括こる機序を明らかにしていくために，血清 中, 肝組織中の HBe 抗原・抗体及び HBV の経時的変
化をより詳細に観察するとともに個体の免疫応答の面か らのアプローチを進めることが急がれる。

\section{結 語}

25例の HBe 抗原陽性慢性肝疾患患者の血清95検体を 用いて経時的に RIA 法で HBe 抗原・抗体を測定し, 同時に血中 DNA-P 活性, Dane 粒子を検索し以下の成 瞔を得た。

1. RIA 法では, HBe 抗原陽性群 の DNA-P 活性 は, 判定保留群, HBe 抗体陽性群に比し有意に高值 を示したが，HBe 抗原陽性57検体中19検体 (33\%) で DNA-P 活性は HBe 抗体陽性群の平均值より低い值を 示した.この DNA-P 活性低值の検体での $\mathrm{HBe}$ 抗原 は, RIA の100倍希积法では大部分陰性となり，MO 法 であ陰性でその抗原価は低いものと考えられた。また， HBe 抗原陽性例の経時的観察から, RIA 法では原血 清で HBe 抗原が陽性の場合には，100倍希釈血清での $\mathrm{HBe}$ 抗原の測定が血中 $\mathrm{HBV}$ の増減の簡便な指標にな り得ることが示された。

2. GOT, GPT の変動の強い慢性肝炎例の経時的観 察では，1） HBe 抗原が常時陽性の症例，2） HBe 抗 原から HBe 抗体ないし判定保留への变動の見られる症 例，3）経過中主として HBe 抗体が検出される症例が 観察された．1)，2)の症例では HBe 抗原価と DNA-P 活性; Dane 粒子は比較的よく一致した变動が認めら れたが，3)の症例では急性増悪時に HBe 抗体が陽性で む DNA-P 活性が高く, かつ, 多数の Dane 粒子が出 現する検体か認められ，HBV と $\mathrm{HBe}$ 抗原・抗体の変 動の問に解離や時相のす゚れが見られる症例が存在するこ とが明らかとなった。 また多くの症例で，急性増悪時に 一過性に HBV の active replication を示唆する所見か 観察されたが, 同様の急性增覀にもかかわらず DNA-P 活性, Dane 粒子の増加中 $\mathrm{HBe}$ 抗原 - 抗体の変動を 伴わない症例わ少数ながら認められ，急性增悪の機序が $\mathrm{HBV}$ HBe 抗原の増減のみでは説明乙難い症例も見 られた。

本研究の一部は「肝炎連絡協議会, 難治性の目炎研究 班」の研究によった。また要旨は第67回日本消化器病学 会総会で報告した。

\section{文 献}

1) Magnius LO, Espmark JA: New specificities in Australia antigen positive sera distinct from the Le Bouvier determinants. J Immunol 109: 
1017-1021, 1972

2) Takahashi K, Imai M, Tsuda F, et al: Association of Dane particles with e antigen in the serum of asymptomatic carriers of hepatitis B surface antigen. J Immunol 117: 102-105, 1976

3) Tong MJ, Stevenson D, Gordon I: Correlation of e antigen, DNA polymerase activity, and Dane particles in chronic benign and chronic active type $B$ hepatitis infections. J Infect Dis 135: $980-984,1977$

4) Alter HJ, Seeff LB, Kaplan PM, et al: Type B hepatitis: The infectivity of blood positive for e antigen and DNA polymerase after accidental needlestick exposure. N Engl J Med 295: 909-913, 1976

5) Imai M, Tachibana FC, Moritsugu Y, et al: Hepatitis B antigen-associated deoxyribonucleic acid polymerase activity and e antigen/anti-e system. Infect Immun 14: 631—635, 1976

6) Okada K, Kamiyama I, Inomata $M$, et al: eantigen and anti-e in the serum of asymptomatic carrier mothers as indicators of positive and negative transmission of hepatitis $B$ virus to their infants. N Engl J Med 294: 746-749, 1976

7) Shikata $\mathbf{T}$, Karasawa $\mathbf{T}$, Abe $\mathbf{K}$, et al: Hepatitis B e antigen and infectivity of hepatitis B virus. J Infect Dis 136: 571-576, 1977

8) Takahashi K, Akahane $Y$, Gotanda $T$, et al: Demonstration of hepatitis $\mathrm{B}$ e antigen in the core of Dane particles. J Immunol 122 : 275279,1979

9) 渡辺省三, 吉川 明, 小島秀男, 他 : 各種 B 型 肝疾患に於ける HBe-system と DNA polymer- ase activity の此較検討. 肝蔵 $20: 531,1979$

10）鈴木 宏，三田村圭二：HBV carrier に打ける e 抗原, e 抗体の臨床的意義. 第 9 回犬山 ンポジム記録. 中外医学社, 東京, 1977, p 197-202

11）赤羽賢浩，清沢研道，長田敦夫，他：HBs 抗 原陽性肝疾患および無症候性 HBs 抗原 carrier における $\mathrm{HBe}$ 抗原抗体系・第 2 編, 経過観察 症例に拈ける $\mathrm{HBe}$ 抗原・抗体の臨床的意義.

肝臓 $21: 391-400,1980$

12) DeGroote J, Desmet VJ, Gedigk $P$, et al: A classification of chronic hepatitis. Lancet 2: $626-628,1968$

13) Mushahwar IK, Overby LR, Frosner G, et al: Prevalence of hepatitis $B$ e antigen and its antibody as detected by radioimmunoassays. J Med Virol 2: 77--87, 1978

14）鈴木 宏, 飯野四郎, 市田文弘, 他 : Radioimmunoassay 法による e 抗原・e 抗体の測定に ついて．肝臓 $21: 1304-1309,1980$

15) Kaplan PM, Greenman RL, Gerin JL, et al: DNA polymerase associated with human hepatitis B antigen. J Virol 12: 995-1005, 1973

16) Yamada G: Electron microscopic observations on hepatitis $B$ antigen-associated particles in the sera of patients with various liver diseases. Acta Med Okayama 28: 27-45, 1974

17) Alberti A, Diana S, Scullard GH, et al: Full and empty Dane particles in chronic hepatitis B virus infection: Relation to hepatitis B e antigen and presence of liver damage. Gastroenterology $75: 869-874,1978$

18) 加藤道夫, 奥山卓正, 益沢 学, 他 : HBe 抗 原抗体系の臨床的検討. 肝葴 $21: 1310-1315$, 1980 


\title{
Changes of $\mathrm{HBeAg}$ and anti-HBe detected by radioimmunoassay in $\mathrm{HBs} A \mathrm{~A}$ -
} positive patients with chronic liver disease: Correlations with DNA polymerase activity and Dane particles

\author{
Motowo Mizuno, Gotaro Yamada, Yuzi Sakamoto, Takashi Nishihara and
}

Hideo NAGASHIMA*

Ninety-five serum specimens of $25 \mathrm{HBsAg}$-positive patients with chronic liver disease were analyzed for $\mathrm{HBeAg}$ /anti-HBe by radioimmunoassay, DNA polymerase activity (DNA-P) and Dane particles. DNA-P in $\mathrm{HBeAg}$-positive group was significantly higher than that in anti-HBe-positive group but about $1 / 3$ of $\mathrm{HBeAg}$-positive samples showed low DNA-P. Ten cases of chronic aggressive hepatitis were observed along acute exacerbation and in 3 of 4 cases continuously with $\mathrm{HBeAg}$, DNA-P and Dane particles maintained high level, whereas 1 of the 4 they were always low. Of 4 cases with seroconversion from $\mathrm{HBeAg}$ to anti-HBe, in 3 cases DNA-P and Dane particles elevated correlatively with titers of $\mathrm{HBeAg}$ and serum transaminase but in 1 they remained low level. In 2 cases anti-HBe was mainly detected during the course and 2 samples at acute exacerbation showed high DNA-P and many Dane particles although they were positive for anti-HBe.

* The First Department of Internal Medicine, Okayama University Medical School (Okayama) 